Royal Netherlands Institute for Sea Research

This is a postprint of:

Ponsoni, L., Aguiar-Gonzáles, B., Nauw, J., Ridderinkhof, H. \& Maas, L.R.M. (2015). First observational evidence of a North Madagascar Undercurrent. Dynamics of atmospheres and oceans, $72,12-20$

Published version: $\underline{\mathrm{dx} . \text { doi.org/10.1016/j.dynatmoce.2015.08.002 }}$

Link NIOZ Repository: www.vliz.be/nl/imis?module=ref\&refid=251569

[Article begins on next page]

The NIOZ Repository gives free access to the digital collection of the work of the Royal Netherlands Institute for Sea Research. This archive is managed according to the principles of the Open Access Movement, and the Open Archive Initiative. Each publication should be cited to its original source - please use the reference as presented.

When using parts of, or whole publications in your own work, permission from the author(s) or copyright holder(s) is always needed. 


\title{
First observational evidence of a North Madagascar Undercurrent
}

\author{
L. Ponsoni a,*, B. Aguiar-González ${ }^{\mathrm{a}}$, J. J. Nauw ${ }^{\mathrm{a}}$, H. Ridderinkhof ${ }^{\mathrm{a}}$, L. R. M. \\ Maas $^{\text {a,b }}$ \\ ${ }^{a}$ NIOZ Royal Netherlands Institute for Sea Research, P.O. Box 59, 1790 AB Den Burg, \\ Texel, The Netherlands \\ ${ }^{b}$ Institute for Marine and Atmospheric Research, Utrecht University, Princetonplein 5, \\ 3584 CC Utrecht, The Netherlands
}

\section{Abstract}

In situ observations reveal a southeastward-directed North Madagascar Un2 dercurrent (NMUC) below and opposite to the equatorward-directed North 3 Madagascar Current (NMC) off Cape Amber, at the northern tip of Mada4 gascar. Results show an undercurrent hugging the continental slope with 5 its core at $460 \mathrm{~m}$ depth and velocities over $0.7 \mathrm{~m} \mathrm{~s}^{-1}$. Its volume trans6 port is estimated to be $3.1-3.8 \mathrm{~Sv}$, depending on the velocity extrapolation 7 methods used to fill in the data gaps near the slope (no-slip and full-slip, 8 respectively). The thermohaline characteristics show a saltier and warmer 9 NMUC, compared to the surrounding offshore waters, transporting mainly South Indian Central Water. Also, strong horizontal gradients of density are found in the NMUC domain. An inshore cell of coastal downwelling due to

${ }^{*}$ Corresponding first author. Tel.: +31 (0)222 369310

Email addresses: lponsoni@nioz.nl (L. Ponsoni), Borja.Aguiar.Gonzalez@nioz.nl (B. Aguiar-González), Janine. Nauw@nioz.nl (J. J. Nauw), Herman.Ridderinkhof@nioz.nl (H. Ridderinkhof), Leo.Maas@nioz.nl (L. R. M. Maas) 
12 Ekman Transport towards the coast is identified, which can explain, at least

13 in part, the strong baroclinic pressure gradients as well as the NMUC devel14 opment and possible persistence.

15

${ }_{16}$ Keywords: North Madagascar Undercurrent, North Madagascar Current,

17 Indian Ocean, Coastal Downwelling, South Indian Central Water 


\section{Introduction}

The South-West Indian Ocean (SWIO) presents one of the most intriguing western boundary regions of all subtropical gyres. Unlike other regions, in the SWIO the Madagascar island imposes a physical barrier to the westward flowing South Equatorial Current (SEC), which reaches the Madagascar coast between $17^{\circ} \mathrm{S}$ and $20^{\circ} \mathrm{S}$ (Fig. 1a). At this location, the SEC bifurcates into two branches: the southward branch feeds into the East Madagascar Current (EMC), which farther south will feed the Agulhas Current (AC); on the other hand, the northward branch feeds into the North Madagascar Current (NMC; Swallow et al. (1988); Chapman et al. (2003); Siedler et al. (2006)), which turns around Cape Amber, at the northern tip of Madagascar, and continues westward towards the east coast of Africa (Swallow et al., 1988).

Besides the surface patterns of the boundary currents, an undercurrent flowing opposite and beneath the surface current appears to be a recurring feature near eastern and western ocean boundaries. At western boundaries, such a feature has been universally observed: the Luzon Undercurrent in the North Pacific (Hu et al., 2013), the East Australian Undercurrent in the South Pacific (Godfrey et al., 1980; Schiller et al., 2008), and the Intermediate Western Boundary Current in the South Atlantic (Evans and Signorini, 1985; da Silveira et al., 2004) are some examples.

In turn, three undercurrents have already been reported to occur in the SWIO: the Agulhas Undercurrent (AUC; Beal and Bryden (1997)), the Mozambique Undercurrent (MU; de Ruijter et al. (2002); van Aken et al. (2004)) and the East Madagascar Undercurrent (EMUC; Nauw et al. (2008);

Ponsoni et al. (2015)), all flowing equatorwards (Fig. 1b). 

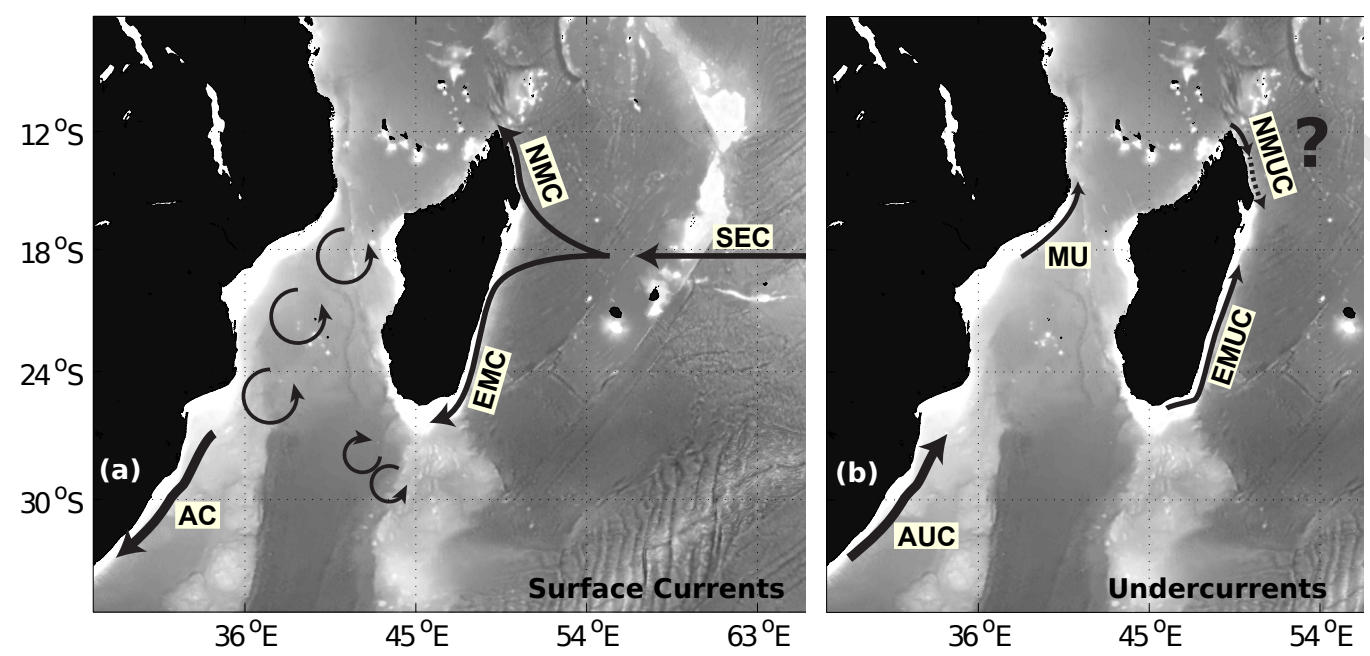

Figure 1: Sketch of the surface currents (a) and undercurrents (b) in the SWIO: South Equatorial Current (SEC), East Madagascar Current (EMC), North Madagascar Current (NMC), Agulhas Current (AC), Agulhas Undercurrent (AUC), East Madagascar Undercurrent (EMUC), Mozambique Undercurrent (MU) and North Madagascar Undercurrent (NMUC).

To the knowledge of the authors, this work presents the first observa-

\section{The ACSEX3 data set}

The results of this study are based on thermohaline and velocity observations carried out on 30 March 2001, as part of the "Dutch-South African Agulhas Current Sources Experiment" (ACSEX). The ACSEX program (de 
Ruijter et al., 2002) was accomplished by three oceanographic surveys around Madagascar on board the RV Pelagia. More precisely, in this paper we use Conductivity-Temperature-Depth (CTD) and Lowered Acoustic Doppler Current Profiles (L-ADCP) from the six innermost stations (Sta18-Sta13) at Transect E1, located northeast of Cape Amber (ACSEX3 survey, Fig. 2). The deepest observation of each vertical profile (200, 580, 1060, 1040, 2520 and $3020 \mathrm{~m}$, from Sta18-Sta13, respectively) is placed near the bottom, on average $17 \mathrm{~m}$ above the seafloor.

The CTD frame was equipped with two synchronized self-contained 300$\mathrm{kHz}$ ADCPs. Vertical profiles of horizontal velocities were achieved either with an inverse solution method (Visbeck, 2002), if near-bottom data were available (stations shallower than $2400 \mathrm{~m}$ ), or shear-based method (Fischer and Visbeck, 1993) for stations deeper than $2400 \mathrm{~m}$. For a complete view of the ACSEX data processing the reader is referred to Nauw et al. (2008).

In addition, monthly fields (from July 1999 to November 2009) and an average field from 25 to 31 March 2001 of wind stress data from the SeaWinds scatterometer, coupled to the NASA's Quick Scatterometer (QuikSCAT) satellite, are analyzed in order to support our interpretations. We use the Version-4 (V4) data products produced by Remote Sensing System and available at www.remss.com (Ricciardulli and Wentz, 2011). The scatterometer spatial resolution is about $25 \mathrm{~km}$. A full description of the SeaWinds is presented by Freilich et al. (1994). 


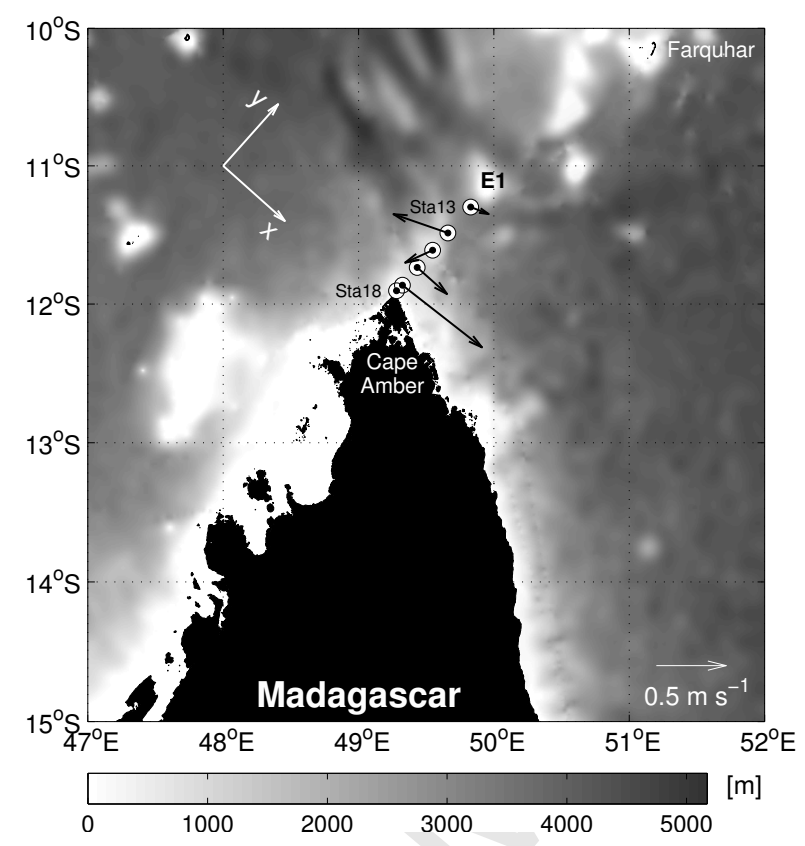

Figure 2: Map of the region of study indicating the oceanographic stations (circles) at transect E1 occupied during the ACSEX3 cruise. From inshore to offshore, the stations are named Sta18-Sta13. Bathymetric contours are drawn in shades of gray. The coordinate system is rotated 41.7 degrees from the north, and it is represented by along-stream $(x)$ and cross-stream $(y)$ components. Vectors show velocities from the L-ADCP, at the depth of $460 \mathrm{~m}$ (NMUC core). Notice that the coordinate axes are plotted only to show the orientation of the coordinate system, since their origins are set at Sta18.

\section{Velocities and Volume Transport}

The two measured components of current velocity were rotated into alongstream $(x)$ and cross-stream $(y)$ directions. The $x$ component represents the main direction of the NMUC, since its flow is markedly perpendicular to Transect E1 (see arrows in Fig. 2). Horizontal extrapolations were performed to fill in the empty data regions created due to the depth difference between two neighboring stations. This is a typical problem, especially pressing in 
regions near a steep continental slope. For the sake of completeness, we apply two boundary conditions in order to compute the volume transport: no-slip and full-slip (Beal and Bryden, 1997; Nauw et al., 2008). The first condition assumes that velocity decreases linearly to zero at the continental slope, while in the second condition the velocity at the continental slope is assumed equal to the nearest measurement at the same depth.

Fig. 3a presents the vertical structure of the along-stream velocity. Negative values (dashed isotachs) represent the NMC flowing northwestward, while positive values on the upper part of the continental slope (solid isotachs, shaded) are related to the southeastward NMUC. The vertical reversal of the flow takes place at Sta17 and Sta16 at a depth of 250 and 320 $\mathrm{m}$, respectively, where the strongly sheared profiles suggest an important baroclinic contribution to the total geostrophic flow.

Fig. 3b shows the vertical profile of geostrophic velocity estimated through the thermal wind relation and from the thermohaline properties (dashed line), for the location in between Sta17-Sta16, as well as the profile of observed velocity interpolated to the same location (solid line). Notice that there is a good agreement in the vertical shear of both profiles at the NMUC vertical range.

At the time of sampling, the total velocity field depicts a NMUC confined from $250 \mathrm{~m}$ depth to the seafloor (near $1060 \mathrm{~m}$ ), hugging the continental slope with a well defined core in which the velocity exceeds $0.7 \mathrm{~m} \mathrm{~s}^{-1}$ at $460 \mathrm{~m}$ at the location of Sta17. Arrows in Fig. 2 show the velocity at this depth level. Notice that the NMUC maximum is comparable to the maximum speed found in the surface NMC $\left(-0.7 \mathrm{~m} \mathrm{~s}^{-1}\right)$. The NMUC extends offshore 


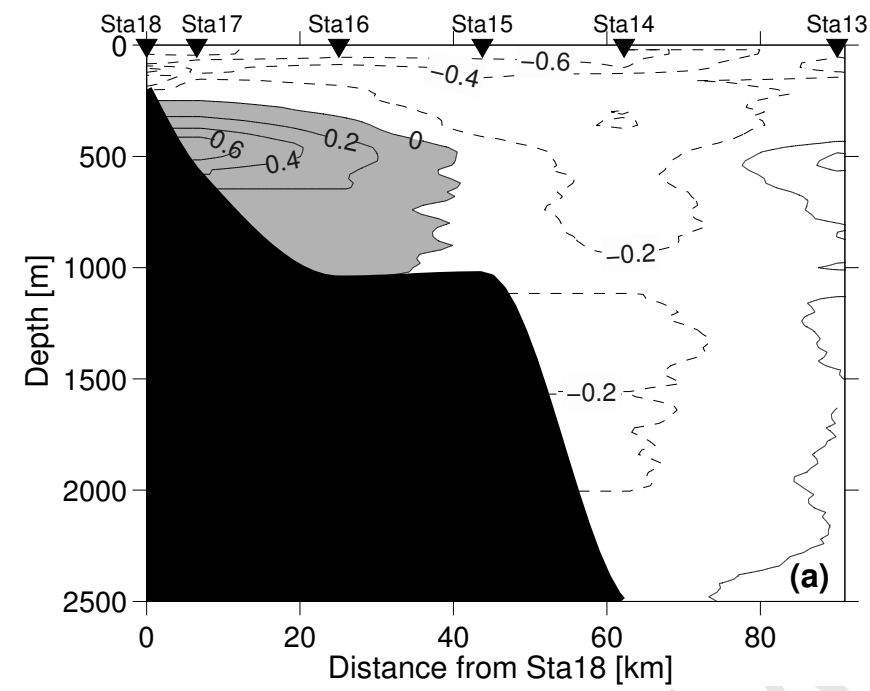

between $25 \mathrm{~km}$ (Sta16) and $44 \mathrm{~km}$ (Sta15).

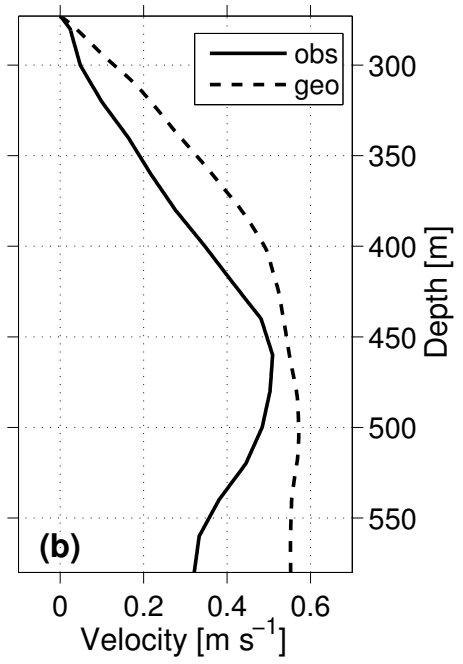

Figure 3: (a) Along-stream velocities in $\mathrm{m} \mathrm{s}^{-1}$. Full-slip extrapolation is applied in this figure. The gray shaded area highlights the NMUC domain. The bathymetry mask is drawn according to the deepest measured point at every station, which took place near the seafloor (about $17 \mathrm{~m}$ from the bottom). (b) Profile of along-stream velocity interpolated in between Sta17 and Sta16 (solid line) and geostrophic velocity estimated from the thermohaline profiles sampled at Sta17 and Sta16 (dashed line). The level of no motion (275 m) was selected according to the observed profile (solid line). 
cruise. The results (not shown) pointed to the absence of eddies in the area of study during the sampling time.

Considering only the NMUC grid points, which are enclosed by the $0 \mathrm{~m} \mathrm{~s}^{-1}$ isotach (gray area in Fig. 3a), mean flows of $0.18( \pm 0.15)$ and $0.16( \pm 0.15)$ $\mathrm{m} \mathrm{s}^{-1}$ are found for full-slip and no-slip extrapolation conditions, respectively.

The NMUC southeastward transport amounts to $3.8 \mathrm{~Sv}\left(1 \mathrm{~Sv}=10^{6}\right.$ $\mathrm{m}^{3} \mathrm{~s}^{-1}$ ) and $3.1 \mathrm{~Sv}$ for full-slip and no-slip conditions. Taking into account the integrated transport in the E1 vertical transect (as plotted in Fig. 3a) the amount of $-18.3 \mathrm{~Sv}$ (full-slip, or $-17.4 \mathrm{~Sv}$ for no-slip) indicates a net northwestward transport. Swallow et al. (1988) and Schott et al. (1988) estimated the NMC volume transport to be $-29.6 \mathrm{~Sv}$ and $-26.9 \mathrm{~Sv}$, respectively, based on geostrophic calculations and observed velocity data. These values represent an integration from surface to 1100 dbar out to $115 \mathrm{~km}$, where their most inshore point is placed offshore of our Sta16 location.

\section{Thermohaline Structure}

The thermohaline and density structures are marked by strong horizontal gradients in temperature ( $T$, Fig 4a), salinity ( $S$, Fig $4 b)$ and potential density anomaly $\left(\sigma_{\theta}\right.$, Fig 4c) which shows that the NMUC lies within the isopycnal range of $26.1-27.4 \mathrm{~kg} \mathrm{~m}^{-3}$, while its core is found near the $26.75 \mathrm{~kg} \mathrm{~m}^{-3}$ isopycnal level (see solid lines in Fig 4d).

The inclination of the isolines towards the coast indicates a NMUC saltier and warmer than waters offshore. Vertical averages calculated in the range of 250-580 m, from the NMUC upper limit to the deepest sampled depth at Sta17, exhibit this difference (Table 1). Notice that horizontal gradients are 

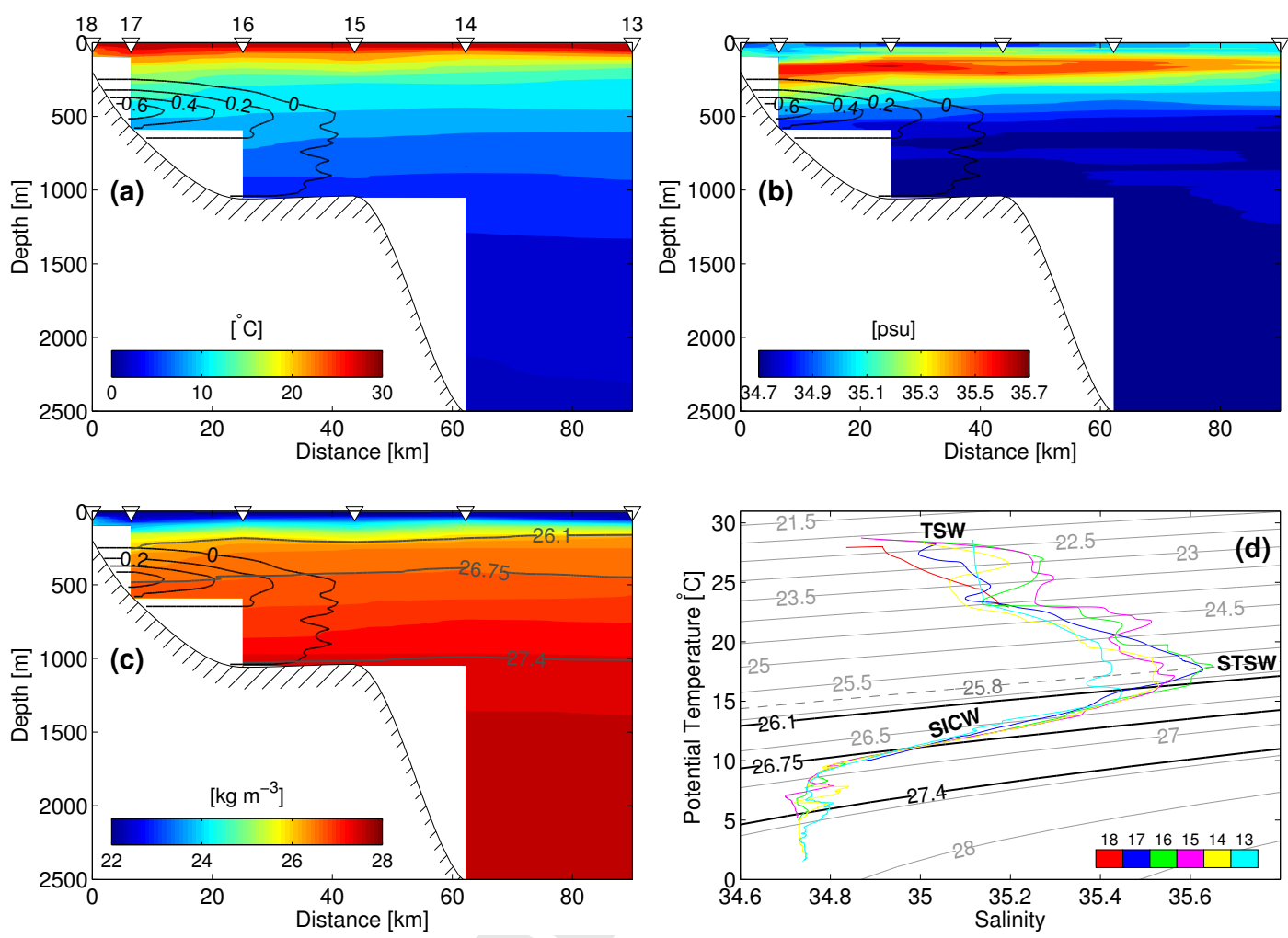

Figure 4: (a) Potential temperature, (b) salinity and (c) potential density anomaly along the $\mathrm{E} 1$ transect. The NMUC isotachs are also plotted (a-c). (d) $\theta-S$ diagram color-coding each E1 station. Abbreviations indicate water masses: Tropical Surface Water (TSW), Sub-Tropical Surface Water (STSW) and South Indian Central Water (SICW)

stronger in between Sta17-Sta16 than in any other combination of neighboring stations. The results also show that the offshore gradients of density are governed mainly by offshore gradients of temperature.

Fig 4d presents the $\theta-S$ diagram for all stations. At surface levels the Tropical Surface Water (TSW) covers the Sub-Tropical Surface Water (STSW), which has a core density of $25.8 \mathrm{~kg} \mathrm{~m}^{-3}$. While TSW is formed in the tropics due to high precipitation and solar warming, STSW is created in the subtrop- 
Table 1: Vertical (250-580 m) averages and standard deviations of potential temperature $(\theta)$, salinity $(\mathrm{S})$ and potential density anomaly $\left(\sigma_{\theta}\right)$.

\begin{tabular}{cccccc}
\hline \hline Station & Sta17 & Sta16 & Sta15 & Sta14 & Sta13 \\
\hline$\theta\left[{ }^{\circ} \mathrm{C}\right]$ & $12.46( \pm 1.85)$ & $11.49( \pm 1.15)$ & $11.17( \pm 1.04)$ & $10.93( \pm 1.15)$ & $10.85( \pm 1.23)$ \\
$\mathrm{S}[\mathrm{psu}]$ & $35.14( \pm 0.19)$ & $35.04( \pm 0.15)$ & $35.00( \pm 0.14)$ & $34.98( \pm 0.15)$ & $34.96( \pm 0.12)$ \\
$\sigma_{\theta}\left[\mathrm{kg} \mathrm{m}^{-3}\right]$ & $26.59( \pm 0.22)$ & $26.71( \pm 0.10)$ & $26.74( \pm 0.09)$ & $26.76( \pm 0.10)$ & $26.76( \pm 0.12)$ \\
\hline \hline
\end{tabular}

ics region due to an excess of evaporation over precipitation and, therefore, it is marked by a maximum in salinity. The lens of high salinity seen in Fig 4b, at subsurface levels, has characteristics of STSW (Wyrtki, 1973). Overlaid by STSW, South Indian Central Water (SICW, also known as Indian Central Water) is found in between the isopycnals of about 26.1 and $27.0 \mathrm{~kg} \mathrm{~m}^{-3}$. This water mass is typified by a narrow $\theta-S$ relation (Emery and Meincke, 1986; Schott and McCreary Jr., 2001) which is expressed as a line in the diagram. The inflexion seen in the $\theta-S$ curve below the $27.0 \mathrm{~kg} \mathrm{~m}^{-3}$ isopycnal reflects an increase in salinity due to influence of Red Sea Water (RSW) (Schott and McCreary Jr., 2001) and marks the transition with intermediate water masses. Ullgren et al. (2012) found similar $\theta-S$ curves in the narrowest part of the Mozambique Channel.

The results show a NMUC mainly carrying SICW, although this water mass also spreads across the offshore zone where the undercurrent is not observed. Also, the undercurrent is not distinguished by this single water mass, since its upper and deeper limits appear to carry waters influenced by STSW and RSW, respectively. 


\section{Coastal Downwelling}

Undercurrents can be both remotely and locally forced. For instance, the Intermediate Western Boundary Current (the undercurrent opposite and underneath the Brazil Current) has a remote origin linked to the depthdependent bifurcation of the South Equatorial Current towards the Brazilian coast, which occurs near $15^{\circ} \mathrm{S}$ at the surface and around $25-27^{\circ} \mathrm{S}$ at intermediate levels (Legeais et al., 2013; Soutelino et al., 2013; Rocha et al., 2014). On the other hand, off Northwest Africa, the alongshore undercurrent and an associated upwelling system are closely coupled to the alongshore component of the local wind (McCreary, 1981).

The development of alongshore undercurrents forced by local alongshore wind, and its associated cross-shore Ekman Transport, was proposed by Yoshida (1959) based on a theoretical model in response to an upwellingfavorable wind. Through a linear stratified ocean model of coastal undercurrents, which was forced with a uniform band of alongshore steady winds, McCreary (1981) and McCreary and Chao (1985) concluded that internal friction and an alongshore pressure gradient are needed for the existence of a realistic undercurrent. Supported by numerical model results, also forced with upwelling-favorable winds, Suginohara (1982) postulated that the development of an alongshore undercurrent is linked to the arrival of the first mode Coastal Trapped Wave (CTW). However, the undercurrent ceases to develop with the arrival of the second mode. Suginohara and Kitamura (1984) also stated that the undercurrent disappeared after long time evolution of the upwelling cell. These authors argued that the upwelling system is insensitive to the absence or presence of bottom friction and, therefore, the bottom 
boundary layer has minor importance on the undercurrent dynamics.

Taking into account that in linear systems (McCreary, 1981; McCreary and Chao, 1985) upwelling and downwelling are symmetric, the same results described above are also expected for a region dominated by downwelling conditions. Indeed, using the Princeton Ocean Model, Middleton and Cirano (1999) complemented the results from Suginohara (1982), where during the first 10-20 days after the set up by the downwelling-favorable winds, the linear system was characterized by the first mode CTW. However, after this initial phase, Middleton and Cirano (1999) showed important differences. Unlike the upwelling scenario, where bottom drag is insignificant, ultimately, this mechanism promotes nonlinear advection of density within the bottom Ekman layer and an increase in the thermal wind shear in the downwelling system. Therefore, an undercurrent can be sustained by a steady downwelling-favorable wind.

We do not have enough in situ data to state whether the NMUC is steady and whether its origin is entirely explained by the mechanism proposed by Middleton and Cirano (1999). But, since our region of study is dominated by downwelling-favorable winds, with similar conditions encountered by these authors, we expect that the local alongshore winds contribute, at least in part, to the NMUC development and possibly to its persistence.

Fig. 5a shows the wind field, surrounding the E1 Transect, averaged from 25 to 31 March 2001 (the oceanographic cruise took place on 30 March 2001). Analogous winds were observed during almost the whole month of March 2001 (Fig. 5b) so that the wind pattern is persistent before and during the cruise and, therefore, the ocean had enough time to adjust to the Ekman 


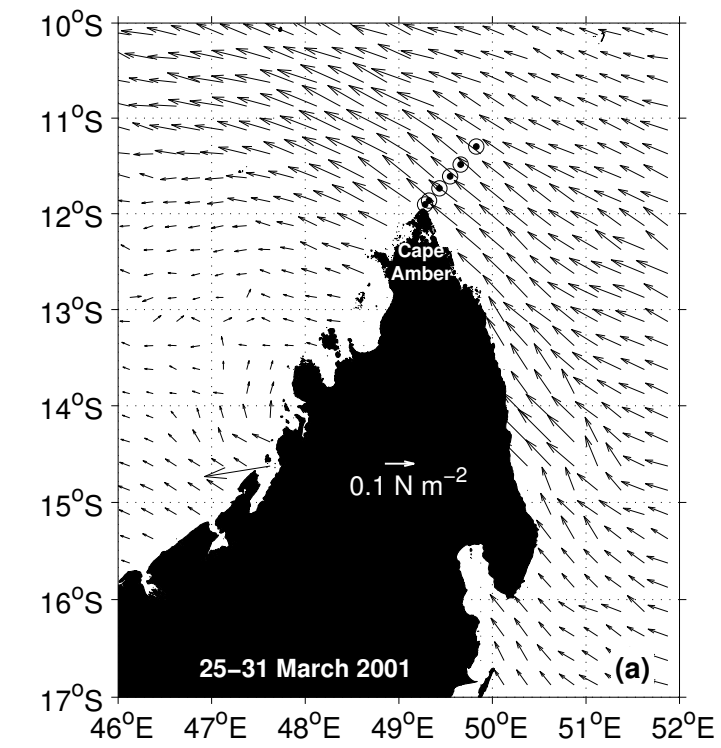

dynamics. Middleton and Cirano (1999) showed that after the first 10 days of a steady downwelling-favorable wind the undercurrent starts to develop and by day 30 the undercurrent is well organized over the slope. Note that the vector scale $\left(0.1 \mathrm{~N} \mathrm{~m}^{-2}\right)$ used as reference in Fig. 5 is equal to the wind stress used in the simulations carried out by Middleton and Cirano (1999). Also, the stratification from the ACSEX transect (Fig 4c) resembles the stratification found by these authors after the establishment of the undercurrent (their Fig. 4c and Fig. 4e) with the isopycnals curving down towards the continental slope.

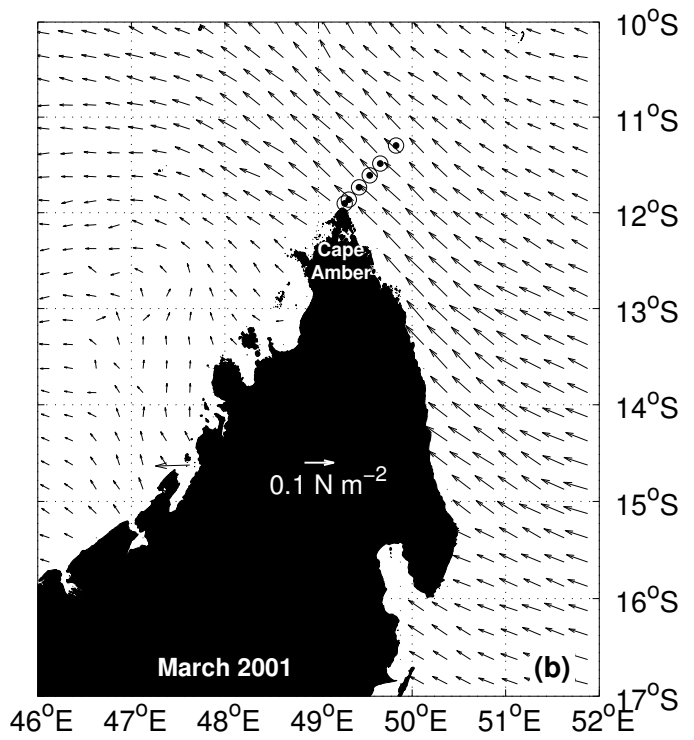

Figure 5: (a) Mean wind stress field for the week 25-31 March 2001. (b) Mean wind stress field for the month of March 2001.

Both mean wind fields shown in Fig. 5 present northwestward winds, perpendicular to the E1 Transect. So, considering that the Ekman Transport, integrated in the Ekman Layer, is $90^{\circ}$ to the left of the wind stress on the 
Southern Hemisphere, such a pattern is responsible for a piling up of water near the coast creating a downwelling system. Notice that the horizontal scale of depression of the thermocline (and pycnocline, Figs. 4a and 4c) towards the coast is similar to the first internal Rossby radius of deformation, estimated to be $\sim 45 \mathrm{~km}$.

Fig. 6a shows the profile of cross-stream velocity from the L-ADCP data, averaged for Sta18-Sta13, while Fig. 6b displays the associated depth-integrated cross-stream Transport $\left(T_{c s}\right)$. Negative values of velocity and transport represent a flow towards the coast. For instance, $T_{c s}=-4.6 \mathrm{~m}^{2} \mathrm{~s}^{-1}$ for the first $90 \mathrm{~m}$ of water column.
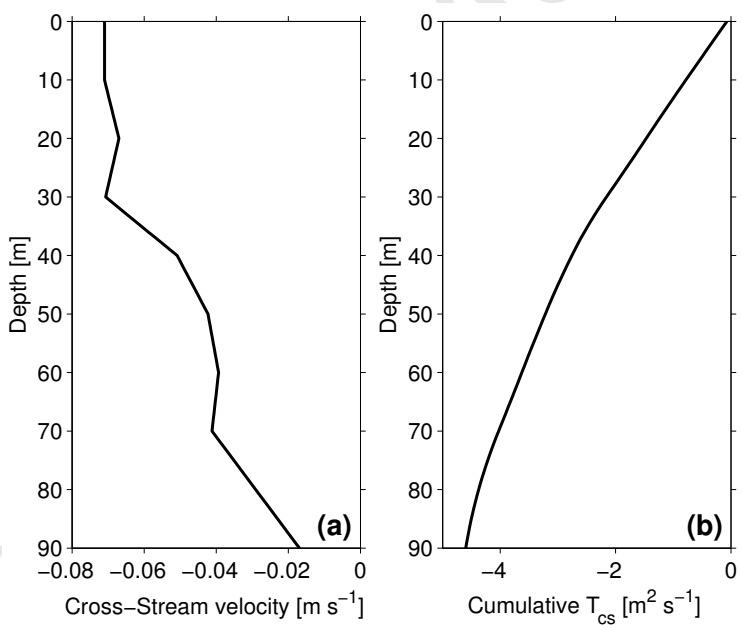

Figure 6: (a) Cross-stream velocity, from the L-ADCP data, averaged for Sta18-Sta13. (b) Cross-stream Transport $\left(T_{c s}\right)$, per unit width, estimated by depth integrating the mean cross-stream velocity profile in (a).

We also calculated the cross-stream Ekman Transport $\left(V_{y}\right)$ at every oceanographic station based on the wind data, as follows: 


$$
V_{y}=-\frac{\tau_{x}}{\rho_{w} f},
$$

$$
H_{E}=\sqrt{\frac{2 A_{V}}{|f|}},
$$


where $A_{V}$ is the coefficient of turbulent viscosity, a poorly known quantity. For a typical choice of $A_{V}=0.1 \mathrm{~m}^{2} \mathrm{~s}^{-1}, H_{E}=82 \mathrm{~m}$. This thickness is coherent with the layer suggested by Stewart (2008) for similar latitude and wind stress. Despite the fact that this is a coarse estimate, and even though such a thickness varies few dozens of meters, the values of $T_{c s}$ in Fig. 6b are, at the very least, consistent with the values of $V_{y}$ estimated for the period of the cruise (Fig. 7a). The Ekman drift is the most likely main contributor of the onshore flow in Fig. 6a.

The QuikSCAT monthly averages show that such a pattern of northwestward wind is persistent during almost the whole year, reinforced in the austral winter (July/August/September) when the winds are stronger, and with the exception of the austral summer (January/February/March) when the winds are weaker. Fig. 7b shows the estimated monthly Ekman Transport (black line and black dots) compared to the mean Ekman Transport for the week from 25 to 31 March 2001 (gray circle). Mean values of -0.30 and $-6.77 \mathrm{~m}^{2} \mathrm{~s}^{-1}$ indicate reduced and strong Ekman transport during summer and winter, respectively. Autumn and spring present intermediate mean values of -4.76 and $-3.83 \mathrm{~m}^{2} \mathrm{~s}^{-1}$. Since downwelling-favorable winds are weaker in summer, one might also expect a reduced NMUC transport in this season.

\section{Discussion and Conclusion}

This paper presents the first observational evidence of a North Madagascar Undercurrent (NMUC). Our results describe a NMUC between 25 and $44 \mathrm{~km}$ wide, and at depths from around 300 to $1000 \mathrm{~m}$ limited by the bathymetry. Hugging the continental slope, the NMUC core is found with 
velocities higher than $0.7 \mathrm{~m} \mathrm{~s}^{-1}$, at $460 \mathrm{~m}$ depth in the vicinity of Sta17 (about $13 \mathrm{~km}$ from the coast).

Its volume transport accounts to $3.8 \mathrm{~Sv}(3.1 \mathrm{~Sv})$ for full-slip (no-slip) boundary condition. This value is comparable with the range of northward transport reported to the East Madagascar Undercurrent (see Fig. 1), which was estimated to be, on average, $1.33( \pm 1.41) \mathrm{Sv}$ and with maxima up to $6 \mathrm{~Sv}$ (Ponsoni et al., 2015). However, the East Madagascar Undercurrent is found much deeper in the water column, since its core is placed at around 1300 m (Nauw et al., 2008; Ponsoni et al., 2015), transporting intermediate waters (while the NMUC transports central waters). From their Transect T8, Nauw et al. (2008) showed an East Madagascar Undercurrent lying between the isopycnals of 27.2 and $27.75 \mathrm{~kg} \mathrm{~m}^{-3}$, while the NMUC is enclosed by the isopycnals of 26.1 and $27.4 \mathrm{~kg} \mathrm{~m}^{-3}$. Thermohaline properties reveal that the NMUC is mainly carrying South Indian Central Water.

Both temperature and salinity experience downwelling due to the Ekman Transport, which contribute to a NMUC being saltier and warmer than the surrounding offshore waters. Potential density increases in the offshore direction, while temperature and salinity decrease. Thus, density gradients are dominated by temperature gradients, while salinity gradients are playing an opposite role, attenuating the density gradients.

The velocity field indicates a strong baroclinic contribution to the NMUC (Sta17 and Sta16), while this geostrophic component appears weaker offshore (Sta15 and Sta14). Probably, this is because coastal processes such as downwelling attenuate farther offshore.

Results suggest that the alongshore winds participate in maintaining the 
density gradients and, consequently, the cross-shore baroclinic pressure gradient. Considering that the downwelling-favorable winds are markedly reduced in summer, one might expect a weaker (or perhaps absent) NMUC during this season. On the other hand, strong and persistent downwelling-favorable winds in winter, autumn and spring might indicate a well developed undercurrent.

Two other aspects of the hypothesis that the NMUC is driven by downwelling-favorable winds might be investigated in future observations. First, its southward extend, which should be limited to $\sim 15^{\circ} \mathrm{S}$, the latitude equatorward of which the winds are downwelling-favorable (see Fig. 5). And, second, the presence of wind-forced anticlockwise propagating coastal trapped waves and the implied mean flow, which is the direction into which these waves propagate on the Southern Hemisphere and which should therefore be observable beyond Cape Amber, on the Western side of Madagascar (e.g., Middleton and Cirano (1999)).

This paper presents a new dynamical feature, the North Madagascar Undercurrent, through analysis of in situ data, in a poorly studied region. But, more important than these results are the new questions arising from this study. For instance, is the NMUC a persistent, or at least a recurrent undercurrent? What is its real spatial extent? Are there clear bands of spatiotemporal variability manifested in the NMUC? These questions have to be addressed in future work based on long term time series and finer spatial resolution. 


\section{Acknowledgements}

The ACSEX program was funded by: Netherlands Organization for Scientific Research (NWO) via its CLIVARNET program, and by the Royal Netherlands Institute for Sea Research, the Institute for Marine and Atmospheric Research Utrecht, and the University of Cape Town. We thank the crew and technicians of RV Pelagia and all who participated in the ACSEX cruises. The first author is grateful to "Coordenação de Aperfeiçoamento de Pessoal de Nível Superior" (CAPES), Brazil, for the concession of a grant. QuikScat data are produced by Remote Sensing Systems and sponsored by the NASA Ocean Vector Winds Science Team. Wind data are available at www.remss.com. We are grateful for the constructive comments by two anonymous referees that helped improve the manuscript.

\section{References}

Beal, L. M., Bryden, H. L., 1997. Observations of an Agulhas Undercurrent. Deep-Sea Res. I 44 (9-10), 1715-1724.

Chapman, P., Di Marco, S. F., Davis, R. E., , Coward, A. C., 2003. Flow at intermediate depths around Madagascar based on ALACE float trajectories. Deep-Sea Res. II 50 (12-13), 1957-1986.

da Silveira, I. C. A., Calado, L., Castro, B. M., Cirano, M., Lima, J. A. M., Mascarenhas, A. S., 2004. On the baroclinic structure of the Brazil Current-Intermediate Western Boundary Current system at $22^{\circ}-23^{\circ} \mathrm{S}$. Geophys. Res. Lett. 31 (L14308), 1-5. 
de Ruijter, W. P. M., Ridderinkhof, H., Lutjeharms, J. R. E., Schouten, M. W., Veth, C., 2002. Observations of the flow in the Mozambique Channel. Geophys. Res. Lett. 29 (10), 140-1-140-3.

Emery, W. J., Meincke, J., 1986. Global water masses: summary and review. Oceanol. Acta 9 (4), 383-391.

Evans, D. L., Signorini, S. S., 1985. Vertical structure of the Brazil Current. Nature 315, 48-50.

Fischer, J., Visbeck, M., 1993. Deep Velocity Profiling with Self-contained ADCPs. J. Atmos. Oceanic Technol. 10, 764-773.

Freilich, M. H., Long, D. G., Spencer, M. W., 1994. Seawinds: a scanning scatterometer for ADEOS-II-science overview. In Geoscience and Remote Sensing Symposium, 1994. IGARSS'94. Surface and Atmospheric Remote Sensing: Technologies, Data Analysis and Interpretation., International (Vol. 2, pp. 960-963). IEEE.

Godfrey, J. S., Cresswell, G. R., Boland, F. M., 1980. Observations of Low Richardson Numbers and Undercurrents near a Front in the East Australian Current. J. Phys. Oceanogr. 10, 301-307.

Hu, D., Hu, S., Wu, L., Li, L., Zhang, L., Diao, X., Chen, Z., Li, Y., Wang, F., Yuan, D., 2013. Direct Measurements of the Luzon Undercurrent. J. Phys. Oceanogr. 43, 1417-1425.

Legeais, J. F., Ollitrault, M., Arhan, M., 2013. Lagrangian observations in the Intermediate Western Boundary Current of the South Atlantic. DeepSea Res. II 85, 109-126. 
McCreary, J. P., 1981. A linear stratified ocean model of the coastal undercurrent. Phil. Trans. R. Soc. Lond. 302 (1469), 385-413.

McCreary, J. P., Chao, S. Y., 1985. Three-dimensional shelf circulation along an eastern ocean boundary. J. Mar. Res. 43, 13-36.

Middleton, J. F., Cirano, M., 1999. Wind-Forced Downwelling Slope Currents: A Numerical Study. J. Phys. Oceanogr. 29 (8), 1723-1743.

Nauw, J. J., van Aken, H. M., Webb, A., Lutjeharms, J. R. E., de Ruijter, W. P. M., 2008. Observations of the southern East Madagascar Current and undercurrent and countercurrent system. J. Geophys. Res. 113 (C08006), 1-15.

Ponsoni, L., Aguiar-González, B., Maas, L. R. M., van Aken, H. M., Ridderinkhof, H., 2015. Long-term observations of the East Madagascar Undercurrent. Deep-Sea Res. I 100, 64-78.

Ricciardulli, L., Wentz, F., 2011. Reprocessed QuikSCAT (V04) Wind Vectors with Ku-2011 Geophysical Model Function, Technical Report 043011. Remote Sensing Systems, Santa Rosa, CA, p. 8.

Rocha, C. B., da Silveira, I. C. A., Castro, B. C., Lima, J. A. M., 2014. Vertical structure, energetics, and dynamics of the Brazil Current System at $22^{\circ} \mathrm{S}-28^{\circ} \mathrm{S}$. J. Geophys. Res. 119 (1), 52-69.

Schiller, A., Oke, P. R., Brassington, G., Entel, M., Fiedler, R., Griffin, D., Mansbridge, J., 2008. Eddy-resolving ocean circulation in the AsianAustralian region inferred from an ocean reanalysis effort. Prog. Oceanogr. 76 (3), 334-365. 
Schott, F., Fieux, M., Swallow, J., Zantopp, R., 1988. The Boundary Currents East and North of Madagascar 2. Direct Measurements and Model Comparisons. J. Geophys. Res. 93 (C5), 4963-4974.

Schott, F. A., McCreary Jr., J. P., 2001. The monsoon circulation of the Indian Ocean. Prog. Oceanogr. 51 (1), 1-123.

Siedler, G., Rouault, M., Lutjeharms, J. R. E., 2006. Structure and origin of the subtropical South Indian Ocean Countercurrent. Geophys. Res. Lett. 33 (L24609), 1-5.

Soutelino, R. G., Gangopadhyay, A., da Silveira, I. C. A., 2013. The roles of vertical shear and topography on the eddy formation near the site of origin of the Brazil Current. Cont. Shelf Res. 70, 46-60.

Stewart, R. H., 2008. Introduction to Physical Oceanography. Orange Grove Texts Plus, Florida.

Suginohara, N., 1982. Coastal Upwelling: Onshore-Offshore Circulation, Equatorward Coastal Jet and Poleward Undercurrent over a Continental Shelf-Slope. J. Phys. Oceanogr. 12, 272-284.

Suginohara, N., Kitamura, Y., 1984. Long-Term Coastal Upwelling over a Continental Shelf-Slope. J. Phys. Oceanogr. 14 (6), 1095-1104.

Swallow, J., Fieux, M., Schott, F., 1988. The Boundary Currents East and North of Madagascar 1. Geostrophic Currents and Transports. J. Geophys. Res. 93 (C5), 4951-4962. 
Ullgren, J. E., van Aken, H. M., Ridderinkhof, H., de Ruijter, W. P. M., 2012. The hydrography of the Mozambique Channel from six years of continuous temperature, salinity, and velocity observations. Deep-Sea Res. I 69, 36-50.

van Aken, H. M., Ridderinkhof, H., de Ruijter, W. P. M., 2004. North Atlantic deep water in the south-western Indian Ocean. Deep-Sea Res. I 51, $755-776$.

Visbeck, M., 2002. Deep Velocity Profiling Ising Lowered Acoustic Doppler Current Profiler: Bottom Track and Inverse Solutions. J. Atmos. Oceanic Technol. 19 (5), 794-807.

Wyrtki, K., 1973. Physical Oceanography of the Indian Ocean. In: Zeitzschel, B., Gerlach, S.A. (Eds), The Biology of the Indian Ocean,. Ecol. Stud. 3, $18-36$.

Yoshida, K., 1959. A Theory of Cromwell Current (the Equatorial Undercurrent) and of the Equatorial Upwelling - An Interpretation in a Similarity to a Costal Circulation. J. Oceanogr. Soc. Japan 15 (4), 159-170. 